\title{
Estimation of health and economic benefits of air pollution abatement for Turkey in 1990 and 1993
}

\author{
Katalin Kovari Zaim \\ Bilkent University, Department of Economics, 06533, Ankara, Turkey
}

\begin{abstract}
An average of 15 million residents of the major cities in Turkey were exposed to particulate matter $\left(\mathrm{PM}_{10}\right)$ and $\mathrm{SO}_{2}$ levels above the World Health Organization (WHO) standards in the 1990-1993 period. An assessment of the health effects due to particulate matter $\left(\mathrm{PM}_{10}\right)$ and exposure to sulphur dioxide $\left(\mathrm{SO}_{2}\right)$ suggests that, if annual $\mathrm{PM}_{10}$ and $\mathrm{SO}_{2}$ levels were reduced to WHO standards, this could have brought a reduction of 5940 and 5480 hospital admissions for respiratory diseases, 121,400 and 112,100 emergency room visits, 8.26 and 6.85 million restricted activity days and 57,000 and 73,000 cases of low respiratory symptoms in children 0-12 years of age in 1990 and 1993 respectively. The estimated annual economic value of avoiding these effects is nearly $0.12 \%$ and $0.08 \%$ of the 1990 and 1993 gross national product (GNP). Furthermore, the results show that, by attaining WHO air pollution standards, 3310 and 3060 lives could have been saved in 1990 and 1993 respectively. $\subseteq 1997$ Published by Elsevier Science Ltd. All rights reserved.
\end{abstract}

Keywords: Air pollution; Economic benefits; Health benefits

\section{Introduction}

About 15 million people living in Turkey's most industrialized urban areas were exposed to particulate matter $\left(\mathrm{PM}_{10}\right)$ and sulphur dioxide $\left(\mathrm{SO}_{2}\right)$ levels which exceeded the World Health Organization (WHO) standards in 1990 and 1993. Hence, one-third of the Turkish population was affected by major air pollution emissions and will be affected in the future due to the average annual urban population growth rate of $5 \%$ which is further enhanced by an urbanization rate of $5.9 \%$ (Statistical Yearbook of Turkey, 1994).

The major sources of air pollution are the combustion of fossil fuels, lead additives in gasoline and heavy industries in the region. Air pollution is exacerbated by the use of high sulphur fuel oil (often with 3\% sulphur content), old vehicle technology with no emission control equipment and often poorly operated, if any, industrial abatement technology.

The objective of this study was to assess the health and economic benefits of reducing $\mathrm{PM}_{10}$ and $\mathrm{SO}_{2}$ levels to the WHO standards in Turkey's major towns in 1990 and 1993. The cities which experienced the highest air pollution levels in 1990 and 1993 are identified, and the health and economic benefits are estimated and discussed.

\section{Urban air pollution in the major cities of Turkey}

According to the Turkish State Statistic Department's report, the most populated cities in 1990 were Ankara, Bursa, Istanbul and Izmir. These cities are the location of the majority of manufacturing industry (see Table 1) (Annual Manufacturing Industry Statistics, 1990; Statistical Yearbook of Turkey, 1994). Istanbul, with about 7 million population, supported $42.35 \%$ of the manufacturing industry in 1990. The industries in Istanbul are mostly concentrated on metal, equipment and textile production. Izmir and Bursa supported $10.1 \%$ and $5.26 \%$ of the total industrial activity respectively, including textiles, manufacture of food, beverage and tobacco production. Erzurum and Sivas, with respective shares of $1.4 \%$ and $0.2 \%$ of industrial activity, were minor contributors to industrial production.

Air pollution has been monitored in Turkey since 1980 . Sulphur dioxide $\left(\mathrm{SO}_{2}\right)$ and particulate matter $\left(\mathrm{PM}_{10}\right)$ are measured daily in the major towns (Statistical Yearbook of Turkey, 1994). In all the cities, the levels of $\mathrm{SO}_{2}$ and $\mathrm{PM}_{10}$ exceeded the WHO standards in all years between 1990 and 1993. The WHO ambient air quality standards for annual averages are $70 \mu \mathrm{g} / \mathrm{m}^{3}$ for $\mathrm{PM}_{10}$ and $50 \mu \mathrm{g} / \mathrm{m}^{3}$ for $\mathrm{SO}_{2}$. The 
Table 1 Population and number of industries in the major cities of Turkey, 1990

\begin{tabular}{lcc}
\hline City & $\begin{array}{c}\text { Population in provincial and } \\
\text { district centre }\left(\mathbf{\times 1 0 ^ { 6 } )}\right.\end{array}$ & $\begin{array}{c}\text { Number of } \\
\text { industries (\%) }\end{array}$ \\
\hline Ankara & 2.84 & 4.30 \\
Bursa & 1.16 & 5.26 \\
Erzurum & 0.4 & 1.40 \\
Istanbul & 6.75 & 42.35 \\
Izmir & 2.13 & 10.10 \\
Kayseri & 0.60 & 1.28 \\
Sivas & 0.38 & 0.20 \\
Others & 54.31 & 35.11 \\
Total & 68.57 & 100 \\
\hline
\end{tabular}

Source: Statistical Yearbook of Turkey, 1994.

annual average air pollution measured in the major cities of Turkey is given in Table 2.

The highest levels of $\mathrm{PM}_{10}$ and $\mathrm{SO}_{2}$ were measured in Sivas and Kayseri during the $1990-1993$ period. In these cities, the population is around 400,000-600,000 and the industrial activity is low (Table 1). Hence, the low quality coal and high sulphur content petroleum consumption in households and transportation seem to be responsible for the high concentrations of $\mathrm{PM}_{10}$ and $\mathrm{SO}_{2}$. The next highest $\mathrm{PM}_{10}$ and $\mathrm{SO}_{2}$ concentrations were measured in Istanbul, with the largest population and highest industrial activity (see Table 1 and Table 2).

The annual average $\mathrm{PM}_{10}$ level decreased by $22 \%, 47 \%$ and $26 \%$, while the level of $\mathrm{SO}_{2}$ decreased by $58 \%, 28 \%$ and 15\%, in Ankara, Bursa and Istanbul between 1990 and 1993. Bursa experienced a $\mathbf{P M}_{10}$ level below the WHO standards in 1993. Erzurum, Izmir, Kayseri and Sivas experienced increases of $83 \%, 30 \%, 76 \%$ and $8.3 \%$ in $\mathrm{PM}_{10}$ and of $90 \%$, $47 \%, 13 \%$ and $4 \%$ in $\mathrm{SO}_{2}$ levels between 1990 and 1993 (Table 2).

The high concentration of air pollutants in many developing countries leads to increased illness, particularly among individuals suffering from respiratory problems, and causes premature death among the elderly. The air pollutants of greatest concern are carbon monoxide, hydrocarbons, sulphur oxides, nitrogen oxides, suspended particulate matter, lead and secondary pollutants such as ozone. However, since only $\mathrm{PM}_{10}$ and $\mathrm{SO}_{2}$ are monitored systematically in Turkey, the health effects associated with these are assessed.

\section{Health benefit estimation}

Epidemiologic studies provide dose-response relationships between ambient level concentrations of $\mathrm{PM}_{10}$ and $\mathrm{SO}_{2}$ and several health outcomes, including premature mortality (PM), respiratory hospital admissions (RHA), emergency room visits (ERV), restricted activity days for adults (RAD), lower respiratory illness for children (LRI), asthma attacks and chronic diseases. The studies which have found statistically significant relationships between the measures of $\mathrm{PM}_{10}$ and $\mathrm{SO}_{2}$ and the above-mentioned health effects have been conducted in several different cities and seasons, thereby incorporating a wide range of climates and population.

Studies linking $\mathbf{P M}_{10}$ to mortality indicate that a $10 \mu \mathrm{g} /$ $\mathrm{m}^{3}$ change in $\mathrm{PM}_{10}$ results in an increased premature mortality between $0.31 \%$ and $1.49 \%$, with a mean value of $0.96 \%$ (Ostro, 1990, 1993; Schwartz, 1991; Pope et al, 1992). Plagiannakos and Parker (1988) found a statistically significant relationship between RHA and ambient sulphate levels. Samet et al (1981) analysed the relationship between ERV and air pollution levels. A regression analysis was performed and daily ERV values were regressed on the maximum temperature and each of the pollutants in separate runs. The study's results indicated that the $\mathrm{PM}_{10}$ and $\mathrm{SO}_{2}$ coefficients were statistically significant and were highly correlated with the daily ERV. RAD include days spent in bed, days missed from work and other days when activities are significantly restricted due to illness Ostro (1983) identified a statistically significant relationship between the $\mathrm{PM}_{10}$ level and RAD. Dockery et al (1989) related $\mathrm{PM}_{10}$ and $\mathrm{SO}_{2}$ levels to chronic cough and bronchitis in children.

Furthermore, studies also indicate that $\mathrm{SO}_{2}$, acting alone or as a surrogate for other sulphur-related species, is associated with increased risk of mortality (Krzyzanowski and Wojtyniak, 1982; Hatzakis et al, 1986; Chinn et al, 1989; Derriennic et al, 1989). Studies that provide evidence of the effect of $\mathrm{SO}_{2}$ on the respiratory system include Bates and Sizto (1983), Dodge et al (1985), Charpin et al (1988), Schwartz et al (1988) and Ponka (1990).

Ostro (1994) used these studies to generate doseresponse information and formulated the health impact of a pollutant as follows

$$
\mathrm{d} H_{i}=b \times \mathrm{POP}_{i} \times \mathrm{d} A
$$

Table 2 Annual average $\mathrm{SO}_{2}$ and $\mathrm{PM}_{10}$ emission levels $\left(\mu \mathrm{g} / \mathrm{m}^{3}\right)$

\begin{tabular}{|c|c|c|c|c|c|c|c|c|}
\hline \multirow[t]{2}{*}{ City } & \multicolumn{2}{|c|}{1990} & \multicolumn{2}{|c|}{1991} & \multicolumn{2}{|c|}{1992} & \multicolumn{2}{|c|}{1993} \\
\hline & $\mathrm{SO}_{2}$ & $\mathbf{P M}_{10}$ & $\mathrm{SO}_{2}$ & $\mathbf{P M}_{10}$ & $\mathrm{SO}_{2}$ & $\mathbf{P M}_{10}$ & $\mathrm{SO}_{2}$ & $\mathbf{P M}_{10}$ \\
\hline Ankara & 170 & 103 & 125 & 83 & 163 & 100 & 72 & 80 \\
\hline Bursa & 185 & 89 & 224 & 101 & 181 & 78 & 133 & 47 \\
\hline Erzurum & 145 & 87 & 176 & 98 & 189 & 129 & 276 & 159 \\
\hline Istanbul & 241 & 118 & 284 & 131 & 247 & 92 & 204 & 87 \\
\hline Izmir & 96 & 77 & 92 & 81 & 162 & 148 & 141 & 100 \\
\hline Kayseri & 161 & 79 & 141 & 74 & 149 & 66 & 182 & 139 \\
\hline Sivas & 260 & 144 & 193 & 169 & 197 & 145 & 269 & 156 \\
\hline WHO standard & 50 & 70 & 50 & 70 & 50 & 70 & 50 & 70 \\
\hline
\end{tabular}


Table 3 Estimated increment in annual health effects associated with unit change in $\mathrm{PM}_{10}$ and $\mathrm{SO}_{2}$ levels

\begin{tabular}{|c|c|c|c|c|c|c|c|}
\hline & \multicolumn{5}{|c|}{$\mathbf{P M}_{\mathbf{1 0}}$} & \multicolumn{2}{|c|}{$\mathrm{SO}_{2}$} \\
\hline & PM/100,000 & RHA 100,000 & ERV/100,000 & RAD/person & LRI/child & PM/100,000 & $\begin{array}{l}\text { RS/1000 } \\
\text { children }\end{array}$ \\
\hline Low & 0.45 & 0.66 & 12.83 & 0.040 & 0.0008 & 0.02 & 0.010 \\
\hline Medium & 0.67 & 1.2 & 23.54 & 0.058 & 0.0016 & 0.05 & 0.018 \\
\hline High & 0.91 & 1.56 & 34.25 & 0.090 & 0.0024 & 0.12 & 0.026 \\
\hline
\end{tabular}

PM, premature mortality; RHA, respiratory hospital admission; RAD, restricted activity days; LRI, lower respiratory illness; ERV, emergency room visit; RS, respiratory symptoms.

Table 4 Abatement levels of $\mathrm{SO}_{2}$ and $\mathrm{PM}_{10}$ needed to reach WHO standards $\left(\mu \mathrm{g} / \mathrm{m}^{3}\right)$

\begin{tabular}{lcccc}
\hline City & \multicolumn{2}{c}{$\mathbf{1 9 9 0}(\mathbf{d} A)$} & & \multicolumn{1}{c}{$\mathbf{1 9 9 3}(\mathbf{d} A)$} \\
\cline { 2 - 5 } & $\mathbf{S O}_{\mathbf{2}}$ & $\mathbf{P M}_{\mathbf{1 0}}$ & $\mathbf{S O}_{\mathbf{2}}$ & $\mathbf{P M}_{\mathbf{1 0}}$ \\
\hline Ankara & 120 & 33 & 22 & 10 \\
Bursa & 135 & 19 & 83 & - \\
Erzurum & 95 & 17 & 226 & 89 \\
Istanbul & 191 & 48 & 154 & 17 \\
Izmir & 46 & 7 & 91 & 30 \\
Kayseri & 111 & 9 & 132 & 69 \\
Sivas & 210 & 74 & 219 & 86 \\
\hline
\end{tabular}

where $\mathrm{d} H_{i}$ is the change in population risk of health effect $i$, $b$ is the slope of the dose-response curve, $\mathrm{POP}_{i}$ is the population at risk of health effect $i, \mathrm{~d} A$ is the change in air pollution under consideration and $i$ is the health effect, such as PM, RHA, ERV, RAD and LRI.

Here, as in other studies, the same dose-response coefficients are adopted to assess the health impacts of $\mathrm{SO}_{2}$ and $\mathrm{PM}_{10}$ for the Turkish urban population. The dose-response coefficients are based on both time-series and cross-section epidemiologic analyses from the USA, Canada and the UK. The use of these results implicitly assumes a similar distribution of baseline factors-health status, chemical composition of pollutants, occupational exposure, seasonality, time spent out of doors, general activity - and that results from other studies can be applied to the study area. This study, like other similar studies on other countries, does not take individuals' defensive actions into account (ie immunization) and does not consider market losses associated with sickness, such as pain and suffering.

\section{Health and economic benefits-results}

The health effects associated with $\mathrm{PM}_{10}$ and $\mathrm{SO}_{2}$ abatement are computed on the basis of the medium doseresponse coefficients $(b)$ depicted in Table 3 . The population at risk $\left(\mathrm{POP}_{i}\right)$ is reported in Table 1 . The abatement levels $(\mathrm{d} A)$ that are needed to reach WHO standards are shown in Table 4.

The levels of PM, RHA, ERV, RAD and LRI are computed. The estimates of health effects achieved by reaching WHO standards for $\mathrm{PM}_{10}$ and $\mathrm{SO}_{2}$ levels are provided in Table 5 and Table 6.

The results indicate that, if the annual $\mathrm{PM}_{10}$ level had been reduced to the WHO standard $\left(70 \mu \mathrm{g} / \mathrm{m}^{3}\right)$, this could have reduced premature mortality cases by 3310 and 3060 in 1990 and 1993 respectively. Furthermore, it could have reduced RHA by 5900 and 5400 and ERV by 121,400 and 112,100 in 1990 and 1993 respectively. When assessing the RAD for the population of age 12 and above, the results showed that the

Table 5 Estimated total health effects associated with PM $_{10}$ level reduction to WHO guidelines in 1990 and 1993

\begin{tabular}{|c|c|c|c|c|c|}
\hline City & $\mathbf{P M}$ & RHA & ERV & $\begin{array}{l}\text { RAD } \times 10^{6} \text { for } 12 \\
\text { years and above }\end{array}$ & $\begin{array}{c}\text { LRIX } 10^{3} \text { for } 0-12 \\
\text { years }\end{array}$ \\
\hline Ankara & $608^{a}, 135^{b}$ & 1087,243 & 22231,4975 & $1.42,0.33$ & 107,21 \\
\hline Bursa & $118,-$ & $212,-$ & $4328,-$ & 0.29 & $19,-$ \\
\hline Erzurum & 69,602 & 123,1079 & 2517,22053 & $0.11,1.02$ & 10,88 \\
\hline Istanbul & 2106,735 & 3771,1316 & 77110,26951 & $0.56,2.00$ & 334,119 \\
\hline Izmir & 36,564 & 65,1010 & 1320,20679 & $0.10,1.54$ & $0.00,81$ \\
\hline Kayseri & 25,504 & 45,902 & 921,18459 & $0.05,1.03$ & $0.00,75$ \\
\hline Sivas & 355,520 & 635,931 & 12985,19045 & $0.62,0.92$ & 54,73 \\
\hline Total & 3317,3060 & 5938,5481 & 121412,112162 & $8.26,6.85$ & 524,457 \\
\hline Rate of change & $-7.75 \%$ & $-7.69 \%$ & $-7.62 \%$ & $-17.07 \%$ & $-12.78 \%$ \\
\hline
\end{tabular}

First value, 1990.

${ }^{\mathrm{b}}$ Second value, 1993.

PM, premature mortality; RHA, respiratory hospital admission; RAD, restricted activity days; LRI, lower respiratory illness; ERV, emergency room visit. 
Table 6 Estimated increment in health effects associated with $\mathrm{SO}_{2}$ level reduction to WHO guidelines in 1990 and 1993

\begin{tabular}{lcc}
\hline City & $\begin{array}{c}\text { Premature } \\
\text { mortality }\end{array}$ & $\begin{array}{c}\text { Respiratory symptoms for } \\
\text { children aged 0-12 years }\end{array}$ \\
\hline Ankara & $163^{\mathrm{a}}, 34^{\mathrm{b}}$ & 1226,225 \\
Bursa & 75,53 & 816,577 \\
Erzurum & 18,50 & 356,974 \\
Istanbul & 619,574 & 3483,3229 \\
Izmir & 47,107 & 54,844 \\
Kayseri & 32,44 & 410,561 \\
Sivas & 39,38 & 736,722 \\
Total & 993,900 & 7084,7132 \\
Rate of change $(\%)$ & -9.36 & -0.67 \\
\hline
\end{tabular}

First value, 1990.

bSecond value, 1993.

Table 7 Doctor's fee per person (annual average prices, TL)

\begin{tabular}{lcc}
\hline City & $\mathbf{1 9 9 0}$ & $\mathbf{1 9 9 3}$ \\
\hline Ankara & 53646 & 161979 \\
Bursa & NA & NA \\
Erzurum & 21264 & 150625 \\
Istanbul & 44118 & 94479 \\
Izmir & 41256 & 92474 \\
Kayseri & NA & NA \\
Sivas & NA & NA \\
\hline
\end{tabular}

Source: Statistical Yearbook of Turkey, 1994 (p. 590).

required abatement could have avoided 8.26 and 6.85 million lost working days. The LRI for children aged between 0 and 12 years could have been decreased by 524,000 and 457,000 in 1990 and 1993 respectively.

Table 6 depicts the estimated health effects associated with $\mathrm{SO}_{2}$ levels measured in 1990 and 1993. If the $\mathrm{SO}_{2}$ levels had been reduced to the WHO standards $\left(50 \mu \mathrm{g} / \mathrm{m}^{3}\right)$, this could have brought a reduction of 993 and 900 cases of premature mortality and 7080 and 7130 cases of respiratory symptoms among children aged between 0 and 12 years in 1990 and 1993 respectively.

\section{Economic evaluation}

The direct annual loss of output caused by absenteeism arising from air pollution is computed by multiplying the estimates of the days lost in 1990 and 1993 due to sickness by the average daily wages. These average daily wages were $28,585 \mathrm{TL}$ and $130,063 \mathrm{TL}$ in urban areas for 1990 and 1993 respectively (Statistical Yearbook of Turkey, 1994). To attach an economic value to RHA, the annual average prices of the doctor's fees were used (see Table 7). The ERV fees were based on the private hospital recordings, ie 167,640 TL/visit/person and 480,000 TL/visit/person in 1990 and 1993 respectively. For the non-available information on doctor's fees in Bursa, Kayseri and Sivas, we used the closest city's prices. The Istanbul price was used for Bursa, whereas doctor's fees in Erzurum were applied for Kayseri and Sivas.

The results indicate that a decrease in $\mathrm{PM}_{10}$ and $\mathrm{SO}_{2}$ levels to WHO standards would have resulted in a total of $48.57 \times 10^{10} \mathrm{TL}$ and $154.08 \times 10^{10} \mathrm{TL}$ savings in 1990 and 1993 respectively (Table 8 ). The total health cost is estimated to be $0.12 \%$ and $0.08 \%$ of 1990 and 1993 gross national product (GNP) respectively. This is rather low when compared with the health costs estimated for the UK (1\% of GNP) in 1993 (Pearce, 1996).

\section{Conclusions}

The health and economic benefits of air quality improvements were estimated. The computations are based on the dose-response coefficients established in several studies. Since the air pollution levels decreased in the most populated and industrialized cities, such as Istanbul, Ankara and Bursa, the health effects and the associated economic costs improved between 1990 and 1993. More specifically, we observed an average $8 \%$ decrease in the levels of RHA and ERV due to air quality improvement. The premature mortality rate decreased by $7.75 \%$ and $9.36 \%$ due to a decrease in the $\mathrm{PM}_{10}$ and $\mathrm{SO}_{2}$ levels. These improvements also brought a $32 \%$ decrease in the economic costs.

The results have several implications. One is that an improvement in air quality can lead to both health and economic benefits to society. Furthermore, we should emphasize that, if more comprehensive and accurate air pollution data (ie ozone, lead) become available, more effects can be evaluated.

Table 8 Estimated economic cost associated with $\mathrm{PM}_{10}$ and $\mathrm{SO}_{2}$ level reduction to WHO guidelines in 1990 and 1993

\begin{tabular}{|c|c|c|c|}
\hline City & RAD $\left(\times 10^{10} \mathrm{TL}\right)$ & RHA and ERV $\left(\times 10^{6} \mathrm{TL}\right)$ & $\begin{array}{l}\text { Respiratory symptoms (RS) for } \\
\text { children aged } 0-12 \text { years } \\
\left(\times 10^{6} \mathrm{TL}\right)\end{array}$ \\
\hline Ankara & $1.20^{\mathrm{a}}, 1.01^{\mathrm{b}}$ & $3321.1,2244.5$ & $65.77,36.44$ \\
\hline Bursa & 1.48 & $379.2,-$ & $43.77,93.46$ \\
\hline Erzurum & $0.37,13.50$ & $200.1,5302.5$ & $7.57,146.71$ \\
\hline Istanbul & $40.57,60.07$ & $12136.96,12801.6$ & $153.66,305.07$ \\
\hline Izmir & $0.57,36.05$ & $178.75,8452.9$ & $2.22,78.04$ \\
\hline Kayseri & $0.26,22.05$ & $100.6,6093.3$ & $8.71,84.50$ \\
\hline Sivas & $2.12,13.15$ & $1097.9,39746.2$ & $15.65,108.75$ \\
\hline Total & $46.54,145.83$ & $17414.63,74640.9$ & $297.35,852.95$ \\
\hline
\end{tabular}

"First value, 1990.

'Second value, 1993. 


\section{References}

Annual Manufacturing Industry Statistics ( $A M I S$ ) (1990) State Institute of Statistics Prime Ministry, Republic of Turkey, Ankara, Turkey

Bates, D V, \& Sizto, R (1983). Air pollution and hospital admissions in southern Ontario: the acid haze effect. Environ. Res., 43, 317-331.

Charpin, D, Kleisbauer, J P, Fondarai, J, Graland, P, Viala, A, \& Gouezo, F (1988). Respiratory symptoms and air pollution changes in children: the Gardanne coal-basin study. Arch. Environ. Health, 43, 22-27.

Chinn, S V, Florey, I, Baldwin, G, \& Gorgol, M (1989). The relation of mortality in England and Wales 1969-73 to measurements of air pollution. J. Epidemiol. Community Health, 35, 174-179.

Derriennic, F, Richardson, S, Mollie, A, \& Lellouch, J (1989). Shortterm effects of sulfur dioxide pollution on mortality in two French cities. Int. J. Epidemiol, 18, 186-280.

Dockery, D W, Speizer, F E, \& Stram, D O (1989). Effects of inhalable particles on respiratory health of children. Am. Rev. Respir. Dis. , 139, 587-597.

Dodge, R, Solomon, P, Moyers, J, \& Hayes, C (1985). A longitudinal study of children exposed to sulfur oxides. Am. J. Epidemiol., 121, $720-736$

Hatzakis, A, Katsouyanni, K, Kalandidi, A, Day, N, and Trichopoulos, D (1986) 'Short-term effects of air pollution on mortality in Athens' Int. J. Epidemiol 15, 73-81.

Krzyzanowski, M, \& Wojtyniak, B (1982). Ten-year mortality in sample of an adult population in relation to air pollution. J. Epidemiol. Community Health, 36, 262-268.
Ostro, B (1983). The effects of air pollution on work loss and morbidity. J. Environ. Econ. Manage, 10, 371-382.

Ostro, B (1990). Environmental pollution and health. Lancet, 340, 1220 1221 .

Ostro, B (1993). The association of air pollution with mortality: examining the case for inference. Arch. Environ. Health, 48, 336-342.

Ostro, B (1994) 'Estimating the health effects of air pollutants: a method with an application to Jakarta' Policy Research Working Paper, 1301 The World Bank, Washington DC

Pearce, D (1996). Economic valuation and health damage from air pollution in the developing world. Energy Policy, 24(7), 627-630.

Plagiannakos, $\mathbf{T}$ and Parker, $\mathbf{J}$ (1988) "An assessment of air pollution effects on human health in Ontario' Ontario Hydro

Ponka, A (1990). Absenteeism and respiratory disease among children and adults in Helsinki in relation to low-level air pollution and temperature. Environ. Res., 52, 34-46.

Pope, C A, Schwartz, J, \& Ransom, M (1992). Daily mortality and PM10 pollution in Utah Valley. Arch. Environ. Health, 42, 211-217.

Samet, J M, Bishop, Y, Speizer, F E, Spengler, J D, \& Ferris, B G (1981). The relationship between air pollution and emergency room visits in an industrial community. J. Air Pollut. Cont. Assoc, 31, 236-240.

Schwartz, J (1991). Particulate air pollution and daily mortality in Detroit. Environ. Res. 56, 204-213.

Schwartz, J, Hasselblad, V, \& Pitcher, H (1988). Air pollution and morbidity: a further analysis of the Los Angeles student nurses data J. Air Pollution Control Assoc., 38, 158-162.

Statistical Yearbook of Turkey (SYT) (1994) State Institute of Statistics Prime Ministry, Republic of Turkey, Ankara, Turkey 